\title{
Clinical utility gene card for: Wolf-Hirschhorn (4p-) syndrome
}

\author{
Agatino Battaglia ${ }^{\star, 1}$, Sarah South ${ }^{2}$ and John C Carey ${ }^{2}$ \\ European Journal of Human Genetics (2011) 19, doi:10.1038/ejhg.2010.186; published online 8 December 2010
}

\section{DISEASE CHARACTERISTICS}

1.1 Name of the disease (synonyms)

Wolf-Hirschhorn syndrome (4p- syndrome, monosomy 4p. Includes

Pitt-Rogers-Danks syndrome).

\subsection{OMIM\# of the disease}

194190.

1.3 Name of the analysed genes or DNA/chromosome segments $4 \mathrm{p} 16.3$.

1.4 OMIM\# of the gene(s)

WHSC1 602952.

LETM1 604407.

\subsection{Mutational spectrum}

Not applicable.

1.6 Analytical methods

Not applicable.

\subsection{Analytical validation}

Not applicable.

1.8 Estimated frequency of the disease

(incidence at birth ('birth prevalence') or population prevalence)

1:50 000 births with a 2:1 female/male ratio.

1.9 If applicable, prevalence in the ethnic group of investigated person

Not applicable.

\subsection{Diagnostic setting}

\begin{tabular}{lcc}
\hline & Yes & No \\
\hline A. (Differential) diagnostics & $\bigotimes$ & $\square$ \\
B. Predictive testing & $\square$ & $\square$ \\
C. Risk assessment in relatives & $\bigotimes$ & $\square$ \\
D. Prenatal & $\bigotimes$ & $\square$ \\
\hline
\end{tabular}

Comment:

\section{TEST CHARACTERISTICS}

\begin{tabular}{|c|c|c|c|c|}
\hline & \multicolumn{2}{|c|}{ Genotype or disease } & \multirow{2}{*}{$\begin{array}{l}\text { A: True positives } \\
\text { B: False positives }\end{array}$} & \multirow{2}{*}{$\begin{array}{l}\text { C: False negative } \\
\text { D: True negative }\end{array}$} \\
\hline & Present & Absent & & \\
\hline \multicolumn{5}{|l|}{ Test } \\
\hline \multirow[t]{2}{*}{ Positive } & $A$ & $B$ & Sensitivity: & $A /(A+C)$ \\
\hline & & & Specificity: & $\mathrm{D} /(\mathrm{D}+\mathrm{B})$ \\
\hline \multirow[t]{2}{*}{ Negative } & $\mathrm{C}$ & $\mathrm{D}$ & Positive predictive value: & $A /(A+B)$ \\
\hline & & & Negative predictive value: & $\mathrm{D} /(\mathrm{C}+\mathrm{D})$ \\
\hline
\end{tabular}

2.1 Analytical sensitivity (proportion of positive tests if the genotype is present)

The technology utilized for testing should be designed to detect deletion of the critical region for WHS, which includes at least portions of the LETM1 and WHSC1 genes. Therefore, either fluorescence in situ hybridization (FISH) with a probe covering this region or genomic microarray with coverage of this region should yield greater than $99 \%$ clinical sensitivity. Standard chromosome studies may not identify microdeletions of this region and would be predicated to have only a $50-60 \%$ clinical and analytical sensitivity. Also, as unbalanced translocations are frequently identified in this syndrome, genomic microarray or FISH with the subtelomeric probes should be considered to identify any concurrent duplications with the $4 \mathrm{p}$ deletion.

As the phenotype and genotype are interrelated for the diagnosis, then the analytical and clinical sensitivity and specificity should all be greater than $99 \%$ if the appropriate testing technology is utilized.

\subsection{Analytical specificity} (proportion of negative tests if the genotype is not present) $>99 \%$.

\subsection{Clinical sensitivity} (proportion of positive tests if the disease is present) The clinical sensitivity can be dependent on variable factors such as age or family history. In such cases a general statement should be given, even if a quantification can only be made case by case. $>99 \%$.

\footnotetext{
${ }^{1}$ Department of Developmental Neurosciences, Stella Maris Clinical Research Institute for Child and Adolescent Neuropsychiatry, Calambrone (Pisa), Italy; ${ }^{2}$ Division of Medical Genetics, Department of Pediatrics, University of Utah, Salt Lake City, UT, USA

${ }^{*}$ Correspondence: Dr A Battaglia, Department of Developmental Neurosciences, Stella Maris Clinical Research Institute for Child and Adolescent Neuropsychiatry, via dei Giacinti 2 , Calambrone (Pisa) 56128, Italy. Tel: +39 5088 6248; Fax: +39 5088 6247; E-mail: abattaglia@inpe.unipi.it
} 
2.4 Clinical specificity

(proportion of negative tests if the disease is not present)

The clinical specificity can be dependent on variable factors such as age or family history. In such cases a general statement should be given, even if a quantification can only be made case by case. $>99 \%$.

2.5 Positive clinical predictive value (lifetime risk to develop the disease if the test is positive) Not applicable.

2.6 Negative clinical predictive value (probability of not developing the disease if the test is negative) Assume an increased risk based on family history for a non-affected person. Allelic and locus heterogeneity may need to be considered.

Index case in that family had been tested:

Not applicable.

Index case in that family had not been tested:

Not applicable.

\section{CLINICAL UTILITY}

3.1 (Differential) diagnosis: The tested person is clinically ffected (To be answered if in 1.10 'A' was marked)

\subsubsection{Can a diagnosis be made other than through a genetic test?}

\begin{tabular}{|c|c|c|}
\hline No & $\square$ (continue with 3.1.4) & \\
\hline \multirow[t]{7}{*}{ Yes } & $\nabla$ & \\
\hline & Clinically & $凶$ \\
\hline & Imaging & $\square$ \\
\hline & Endoscopy & $\square$ \\
\hline & Biochemistry & $\square$ \\
\hline & Electrophysiology & $\square$ \\
\hline & Other (please describe) & \\
\hline
\end{tabular}

3.1.2 Describe the burden of alternative diagnostic methods to the patient

Not applicable.

3.1.3 How is the cost effectiveness of alternative diagnostic methods to be judged?

Not applicable.

3.1.4 Will disease management be influenced by the result of a genetic test?

\footnotetext{
No $\square$

Yes $\bigotimes$

Therapy (please Rehabilitation therapy with enrolment in a personalised describe) rehabilitation program, covering motor aspects, cognition, communication, and socialisation. Early intervention followed by appropriate school placement are recommended. Antiepileptic therapy: in the authors' experience, the atypical absences are well controlled by valproic acid, alone or associated with ethosuccimide, whereas carbamazepine may worsen the electroclinical picture. Other medical therapies as requested by the clinical condition. Having a diagnosis prevents the performance of unnecessary testing on the common diagnostic odyssey.
}

\section{(Continued)}

$\begin{array}{ll}\text { Prognosis } & \text { Depends on the presence or absence of major malformations, } \\ \text { (please describe) } & \text { and type and severity of seizures and their management. } \\ & \text { Larger deletions can be associated with the risk of major } \\ & \text { malformations and a more severe phenotype. } \\ \text { Management } & \text { Physical, neurological and functional evaluations (cognitive, } \\ \text { (please describe) } & \text { language, and motor development and social skills) are } \\ & \text { mandatory. Proper waking/sleeping video-EEG-polygraphic } \\ & \text { studies in infancy and childhood to detect type of seizures } \\ & \text { (particularly atypical absences that may be clinically missed } \\ & \text { in such children) are highly recommended. Evaluation for } \\ & \text { feeding problems and gastroesophageal reflux as needed. } \\ & \text { Search for skeletal anomalies, with referral for orthopaedic } \\ & \text { and physical therapy evaluation, is essential. Heart examina- } \\ & \text { tion, ophthalmology consultation; otolaryngological evaluation } \\ & \text { and audiological screening should be performed in each } \\ & \text { individual at diagnosis, even in the absence of overt anoma- } \\ & \text { lies. Renal function testing and renal ultrasonography } \\ & \text { are mandatory, to detect structural renal anomalies and/or } \\ & \text { vesicoureteral reflux. Planning for transition to adulthood } \\ & \text { should begin in adolescence. }\end{array}$

3.2 Predictive Setting: The tested person is clinically unaffected but carries an increased risk based on family history

(To be answered if in 1.10 ' $\mathrm{B}$ ' was marked)

Not applicable.

\subsubsection{Will the result of a genetic test influence lifestyle and prevention? \\ If the test result is positive (please describe): \\ Not applicable.}

If the test result is negative (please describe):

Not applicable.

3.2.2 Which options in view of lifestyle and prevention does a person at-risk have if no genetic test has been done (please describe)?

Not applicable.

3.3 Genetic risk assessment in family members of a diseased person (To be answered if in 1.10 ' $\mathrm{C}$ ' was marked)

Risk to family members depends on the mechanism of origin of the deletion. If the deletion is a simple deletion and the parents are phenotypically normal, they are very unlikely to carry a deletion. If the deletion is part of an unbalanced translocation, then there is a significant risk (greater than 50\%) that either parent would carry a balanced version of the translocation.

3.3.1 Does the result of a genetic test resolve the genetic situation in that family?

Yes, as it will likely determine the aetiology of the disease and the recurrence risk.

3.3.2 Can a genetic test in the index patient save genetic or other tests in family members?

It will likely result in more genetic testing within other family members if an unbalanced translocation is identified.

3.3.3 Does a positive genetic test result in the index patient enable a predictive test in a family member?

For certain types of genetic results (eg, unbalanced translocation) this would increase the likelihood of an abnormal genetic test in either parent 


\subsection{Prenatal diagnosis}

(To be answered if in 1.10 'D' was marked)

Prenatal testing is available to families in which one parent is known to be a carrier of a chromosome rearrangement.

\subsubsection{Does a positive genetic test result in the index patient enable a prenatal diagnostic?}

Not necessarily, parental testing should be done first to determine recurrence risk. ${ }^{1-21}$

\section{IF APPLICABLE, FURTHER CONSEQUENCES OF TESTING}

Please assume that the result of a genetic test has no immediate medical consequences. Is there any evidence that a genetic test is nevertheless useful for the patient or his/her relatives? (Please describe)

\section{ACKNOWLEDGEMENTS}

This work was supported by EuroGentest, an EU-FP6-supported NoE, contract number 512148 (EuroGentest Unit 3: 'Clinical genetics, community genetics and public health', Workpackage 3.2).

1 Battaglia A: Deletion 4p: Wolf-Hirschhorn syndrome; in Cassidy SB, Allanson JE (eds): Management of Genetic Syndromes. Hoboken, NJ: Wiley-Liss and Sons Inc., 2010, pp 249-261.

2 Battaglia A, Carey JC: Update on the clinical features and natural history of Wolf Hirschhorn syndrome (WHS): experience with 48 cases. Am J Hum Genet 2000; 67: 127.

3 Battaglia A, Carey JC: Seizure and EEG patterns in Wolf-Hirschhorn (4p-) syndrome. Brain Dev 2005; 27: 362-364.

4 Battaglia A, Carey JC, Cederholm P, Viskochil DH, Brothman AR, Galasso C: Natural history of Wolf-Hirschhorn syndrome: experience with 15 cases. Pediatrics 1999; 103 : 830-836.

5 Battaglia A, Carey JC, Cederholm P, Viskochil DH, Brothman AR, Galasso C: Storia naturale della sindrome di Wolf-Hirschhorn: esperienza con 15 casi. Pediatrics 1999; 11: 236-242.

6 Battaglia A, Carey JC, Thompson JA, Filloux FM: EEG studies in the Wolf-Hirschhorn (4p-) syndrome. EEG Clin Neurophysiol 1996; 99: 324
7 Battaglia A, Carey JC, Viskochil DH, Cederholm P, Opitz JM: Wolf-Hirschhorn syndrome (WHS): a history in pictures. Clin Dysmorphol 2000; 9: 25-30.

8 Battaglia A, Carey JC, Wright TJ: Wolf-Hirschhorn (4p-) syndrome. Adv Pediatr 2001; 48: 75-113.

9 Battaglia A, Filippi T, Carey JC: Update on the clinical features and natural history of Wolf-Hirschhorn (4p-) syndrome: experience with 87 patients and recommendations for routine health supervision. Am J Med Genet Part C Semin Med Genet 2008; 148C: 246-251.

10 Battaglia A, Filippi T, South ST, Carey JC: Spectrum of epilepsy and EEG patterns in Wolf-Hirschhorn syndrome: experience with 87 patients. Dev Med Child Neurol 2009; 51: 373-380.

11 Fisch GS, Battaglia A, Parrini B, Youngblom J, Simensen R: Cognitive-behavioral features of children with Wolf-Hirschhorn syndrome: preliminary report of 12 cases. Am J Med Genet. 2008; 148C: 252-256.

12 Giglio S, Calvari V, Gregato G et al: Heterozygous submicroscopic inversions involving olfactory receptor-gene clusters mediate the recurrent $\mathrm{t}(4 ; 8)(\mathrm{p} 16 ; \mathrm{p} 23)$ translocation. Am J Hum Genet 2002; 71: 276-285.

13 Maas NM, Van Buggenhout G, Hannes F et al: Genotype-phenotype correlation in 21 patients with Wolf-Hirschhorn syndrome using high resolution array comparative genome hybridisation (CGH). J Med Genet 2008; 45: 71-80.

14 South ST, Bleyl SB, Carey JC: Two unique patients with novel microdeletions in 4p16.3 that exclude the WHS critical regions: implications for critical region designation. Am J Med Genet A 2007; 143A: 2137-2142.

15 South ST, Whitby H, Battaglia A, Carey JC, Brothman AR: Comprehensive analysis of Wolf-Hirschhorn syndrome using array CGH indicates a high prevalence of translocations. Eur J Hum Genet 2008; 16: 45-52.

16 Wieczorek D, Krause M, Majewski F et al: Effect of the size of the deletion and clinical manifestation in Wolf-Hirschhorn syndrome: analysis of 13 patients with a de novo deletion. Eur J Hum Genet 2000; 8: 519-526.

17 Wieczorek D, Krause M, Majewski $\mathrm{F}$ et al: Unexpected high frequency of de novo unbalanced translocations in patients with Wolf-Hirschhorn syndrome (WHS). J Med Genet 2000; 37: 798-804.

18 Wright TJ, Ricke DO, Denison $\mathrm{K}$ et al: A transcript map of the newly defined $165 \mathrm{~kb}$ Wolf-Hirschhorn syndrome critical region. Hum Mol Genet 1997; 6: 317-324

19 Zollino M, Lecce R, Fischetto $\mathrm{R}$ et al: Mapping the Wolf-Hirschhorn syndrome phenotype outside the currently accepted WHS critical region and defining a new critical region, WHSCR-2. Am J Hum Genet 2003; 72: 590-597.

20 Zollino M, Lecce R, Selicorni A et al: A double cryptic chromosome imbalance is an important factor to explain phenotypic variability in Wolf-Hirschhorn syndrome. Eur J Hum Genet 2004; 12: 797-804.

21 Zollino M, Murdolo M, Marangi $G$ et al: On the nosology and pathogenesis of Wolf-Hirschhorn syndrome: genotype-phenotype correlation analysis of 80 patients and literature review. Am J Med Genet Part C Semin Med Genet 2008; 148C: 257-269. 